\title{
Lexis
}

Journal in English Lexicology

17 | 2021

Humor, creativity and lexical creation

\section{Translating humorous lexical creations in children's literature: The case of Roald Dahl's Gobblefunk}

Inès Zorgati

\section{OpenEdition}

Journals

Electronic version

URL: https://journals.openedition.org/lexis/5589

DOI: $10.4000 /$ lexis.5589

ISSN: 1951-6215

Publisher

Université Jean Moulin - Lyon 3

\section{Electronic reference}

Inès Zorgati, "Translating humorous lexical creations in children's literature: The case of Roald Dahl's Gobblefunk", Lexis [Online], 17| 2021, Online since 15 August 2021, connection on 23 August 2021.

URL: http://journals.openedition.org/lexis/5589 ; DOI: https://doi.org/10.4000/lexis.5589

This text was automatically generated on 23 August 2021.

\section{cc) (i) ()}

Lexis is licensed under a Creative Commons Attribution-NonCommercial-NoDerivatives 4.0 International License. 


\section{Translating humorous lexical creations in children's literature: The case of Roald Dahl's Gobblefunk}

Inès Zorgati

\section{Introduction}

1 Children's literature, a term perhaps as difficult to define as humor, overflows with examples of linguistic manipulations and lexical creations, such as wordplay, puns, nonce words, idioms, dialects and creative names. From the origin of the genre with the early nursery rhymes and the nonsensical writings of Edward Lear and Lewis Carroll, to the work of more recent authors such as Dr. Seuss, Lemony Snicket or Roald Dahl, inventing new terms, playing with words and by extension with language itself has progressively become a characteristic of the genre. Lexical creations being particularly interesting in this aspect, this paper will focus on their functions in children's literature, as well as on the way they can be created and on the challenges when it comes to translating them into another language. Although inventing words in a literary context may serve different purposes, this paper focuses mainly on the humorous effect they may have on young readers. Both the concepts of humor and of children's literature being challenging to define and subjects to academic debates, a preliminary clarification of these terms, as well as what is precisely meant by lexical creations, would be necessary to set the frame of this paper's analysis. Humor being indeed likely to differ from one individual to another, the boundaries of the term seem almost endless, which increases the difficulty of agreeing on a clear definition. Similarly, what is considered as children's literature has regularly changed over time and attempts to specifically define the genre have been faced with the obligation to take this constant evolution into account. In order to analyze the linguistic mechanisms behind such lexical creations and their humorous effect on readers of children's literature, this paper will use as a case study the work of a particularly prolific author in terms of nonce words, Roald Dahl and his made-up vocabulary called 
Gobblefunk, mostly present in his 1982 novel, The BFG. This article will then explore the translation processes of such lexical creations, using the 1984 French translation of the book by Jean-François Ménard, Le Bon Gros Géant. This analysis will aim at exploring the different challenges of translating the humorous function of nonce words and will reflect on the possible strategies available to translators when it comes to play with language... in another language.

\section{Humorous lexical creations in children's literature}

2 When it comes to concepts that present a certain difficulty for scholars to define, both children's literature and humor are definitely concerned. Their limits are indeed far from being clearly set and their characteristics seem in constant evolution. Their links with lexical creations can be an original way of approaching these delicate terms, and the first part of this article will therefore explore whether they can be considered as a characteristic of this literary genre and if producing a humorous effect is their main function or just one among many.

\subsection{A characteristic of the genre?}

3 To be able to classify lexical creations as a possible characteristic of children's literature, it is first and foremost necessary to point out the different challenges of defining the notion. What is precisely meant by lexical creations also needs to be clarified as children's literature is often overwhelmed by all sorts of linguistic manipulations, lexical creations being just one of them.

\subsubsection{Children's literature: a challenging definition}

4 Over time, and especially over the last three centuries as children's literature has been progressively given more academic attention and consideration (Taxel [2002: 152]), numerous definitions of the term have emerged, almost all of them having in common their insistence on the particular difficulty to reach a consensus among scholars on what children's literature precisely is. Epstein [2012: 2] suggests that a possible reason for such a variety of opinions on the matter lies in the very changing nature of children's literature, which evolves rapidly, following "society's understanding of what children's needs are". She furthermore states that the challenge of explaining clearly what children's literature is directly echoes the complexity of defining the concept of childhood itself (Epstein [2012: 3]). If children's literature is indeed undeniably linked to children themselves, subtleties remain concerning what kind of texts should or not be included in the definition of the genre. While O'Sullivan [2005:1] incorporates exclusively what has been "written or adapted specifically for children by adults", other scholars such as Oittinen [2000: 61] consider that the definition should also take into account the texts written by children themselves. For Bator [1983:3], it is moreover important to make the distinction between what children actually read and what was intended for them, whereas Hunt [2002: 14] has pointed out the necessity of considering the notion that children's literature is "also meant to be 'good' for children". According to Nodelman [2008: 137], it is precisely its complex definition, or rather definitions, that give children's literature its profound and rich nature: 
I believe that an attempt to understand differing definitions in terms of their complex relationships with each other will reveal not just how they interconnect but also how their connections imply an underlying and ongoing set of concerns concerns significantly related to ideas about children and about the place of literature in the lives of children - that give shape and consistency to the genre of children's literature as a whole and reveal ways in which apparently quite different texts similarly belong to that genre.

Children's literature is indeed so diverse and complex despite its sometimes apparent simplicity that perhaps a more relevant way of defining it would be to analyze some of its predominant characteristics, some of the common points shared by most texts which are considered as belonging to the genre.

\subsubsection{The main characteristics of children's literature}

6 In her now famous description, McDowell [1973: 141-142] presents one of the first sets of characteristics that allows readers to differentiate children's literature from adults' fiction:

Children's books are usually shorter, they tend to favour an active rather than a passive treatment, with dialogue and incident rather than description and introspection; child protagonists are the rule; conventions are much used; the story develops within a clear-cut moral schematism; children's books tend to be optimistic rather than depressive; language is child-oriented; plots are of a distinctive order; probability is often discarded; and one could go on endlessly talking of magic, fantasy, simplicity and adventure.

There is then a clear set of characteristics that can help identify books that are likely to belong to the genre of children's literature: their length, their writing style and tone, the age of their main characters and the way the story is organized for instance can indeed be considered as helpful clues. In her analysis, Oittinen [2002: 5-6] adds the relevant facts that children's literature often relies on the use of illustrations and that "reading aloud, too, is a characteristic of books for children". But perhaps a more original point of view can be examined through Rose's [1992: 78] claim that

[t]he history of children's fiction should be written, not in terms of its themes or the content of its stories, but in terms of the relationship to language which different children's writers establish for the child.

The question of language has indeed been central to children's literature as far as the genre originates. Poix [2018: \$42] notes that "there is a strong history in children's literature of defying language conventions, referred to as nonsense". From the early nursery rhymes and nonsensical poems and writing of Edward Lear and Lewis Carroll during the $19^{\text {th }}$ century, playing with language, exploring its limits and even inventing new words and expressions have in fact played an important role in the development of the genre. This tendency has moreover never declined as some of the most famous children's and young adults' literature authors such as J.R.R. Tolkien, Dr. Seuss, Lemony Snicket, J.K. Rowling and of course Roald Dahl have, each in their own way, included linguistic manipulations in their writing. What Epstein [2012:18] calls "expressive language" has progressively become indissociable from the genre and can now be considered as one of the main characteristics of children's literature. She includes in the term all types of unusual lexical items such as "neologisms, names, idioms, allusions, wordplay and dialects" (Epstein [2012: 18]). According to Poix [2019: 35-36], these linguistic manipulations have a set of characteristics when appearing in the context of children's literature, among which are the facts that they are omnipresent, 
singular, that they often give way to an interaction between the child and the reader or the writer, that they have a short lifespan, that they are correlated with the linguistic skills of the child and that they may require an additional interpretation effort. It is therefore necessary to take language manipulations into account when trying to define the genre and its characteristics. Although all types of "expressive language" are worthy of special consideration, invented words are particularly interesting in terms of linguistic and translation analysis, especially in the context of children's literature.

\subsubsection{Lexical creations: neologisms vs occasionalisms}

9 Even though Epstein [2012] uses the term "neologisms" in her analysis, it is important to distinguish them from invented words in the context of literature as they do not serve the same functions and do not share the same characteristics. Indeed, if a neologism can be commonly defined as "a word or phrase which is new to the language; one which is newly coined" [OED3], Munat [2007: 169] explains her inclination to use another term to define words that have been created in a literary text: "nonce formations". According to her, the main contrast between the two terms is their finality. Neologisms have indeed entered the lexicon while nonce formations are in fact barred from this privilege due to their "heavy context dependence and lack of utility in the world at large" (Munat [2007: 169]). Words invented by authors for a children's book are indeed not very likely to find a utility outside the frame of the story they originate in, and should therefore not be considered as neologisms from which they differ in this way. Another term used to designate the lexical creations in literature is "occasionalisms", which, according to Mattiello [2017:25], can be employed interchangeably with the expressions "nonce formations" or "nonce words". Poix [2018: \$6] moreover insists on the fact that contrary to neologisms which aim at enriching the language, literary occasionalisms are instead created in order to "enrich the text itself". The function of such words is therefore not purely lexical, they are not meant to fill a gap in the everyday vocabulary or to offer a linguistic solution to a communication problem, but to create a certain "poetic effect" (Poix [2018: \$10]). "Occasionalisms", "nonce formations", "nonce words" and "lexical creations" are then the terms I have chosen to use for the purpose of this article analyzing their characteristics, functions, formation and methods to translate them effectively.

\subsection{Occasionalisms and humor}

10 If occasionalisms thus serve, as a general rule, not a communication purpose but a more creative, poetic one, these nonce formations can also present, in the context of children's literature, a certain number of different functions. Yet, Epstein [2012: 33] remarks:

An obvious first concern is that children are still in the process of learning their native language. So it could be confusing for children to experience new words that may not be accepted ones in their language.

11 It is interesting to note that, of all kinds of literature, children's literature seems nevertheless to be rather prolific in terms of lexical creations. What could then be the reasons why children's authors often choose to create new lexical items instead of using already established ones, taking then the risk to cause confusion and therefore a possible disinterest of their readers? 


\subsubsection{Functions of occasionalisms in children's literature} can easily explain the tendency of many authors of children's literature such as Dahl to use them in abundance. Epstein [2012:20-21] draws a rather complete list of such reasons for using "expressive language" which, by extension, applies to occasionalisms as well. From her long list, a few reasons seem to stand out as other studies have corroborated them. I have therefore chosen to emphasize these functions as they are the ones which would be most useful in my analysis of Dahl's occasionalisms in The BFG. Expressive language is therefore, according to Epstein [2012: 20-21], likely to be used in order

[t]o parody, to entertain, [...] to explain difficult things in a simpler way, to reflect a character/setting, [...] to teach, to subtly refer to taboo/impolite/sensitive issues, to give a text energy, to make readers pay more attention to the text and its message, $[. .$.$] as rituals or insults, [...] to be funny, [...] to reveal the power of language or the$ limits of language.

Nonce formations, by their unusual and often surprising nature, are also a way of catching the reader's attention, a way for an author to be original and make their text stand out. This is what Lipka [2002: 189] and Hohenhaus [2007: 23] call "attentionseeking devices", and they may indeed perform as an attention caller on different points. First, it seems that such linguistic manipulations are a way to raise attention on language itself, how it is used and how it can be played with. As Lathey [2015: 98] underlines, playing with language in children's literature is an effective way to "increase their metalinguistic awareness". The readers, however young, learn that creating words is possible as well as they realize the possibility for lexical items to have a double meaning. According to Poix [2019: 49], playing with words is a way of helping children understand the rules of language in order to be able to divert from them. Another important effect of nonce words on readers is that they are likely to create an impression of reality: if a word exists to name an object, a character or a place, then it immediately gives life to what it names. A phenomenon called "hypostatisation", according to Munat [2015: 97], which gives the illusion of reality and is therefore often used in children's literature as well as in science-fiction texts. Finally, perhaps one of the most important functions of occasionalisms is their ludic aspect. They are indeed likely to produce a humorous effect on readers, which is often what writers of children's fiction look for. Lathey [2015: 98] insists on the fact that wordplay and other linguistic manipulations are "a source of great amusement and irony in children's fiction and poetry" and Poix [2018: \$28] points out that nonce formations are part of a "recreational process" from the author's part. This humorous effect, however central to the presence of occasionalisms in children's literature, is not easy to explain as the definition of humor is vast and as the characteristics of what is funny are very likely to differ from one person to the next.

\subsubsection{Humor. another impossible definition?}

14 Humor may indeed be as hard to define, probably harder still, than children's literature. Although the concept is one we are all familiar with, putting it into words that could embody the complexity and the variety of humor is not an easy task for scholars. Perhaps the personal nature of each individual's sense of humor makes it in 
fact impossible to define it in a universal way. For Chiaro [2010:13], the difficulty to define humor also lies in the fact that the term seems to include a large number of distinct concepts "such as comedy, fun, the ridiculous, nonsense...", but she still attempts to formulate a definition in terms of body response:

Exhilaration incorporates reactions such as laughter and smiling to the humor response as well as a series of psychological changes. Possibly most important of all, exhilaration includes the emotional effect which is experienced to a humorous stimulus, an effect which leaves the recipient with that agreeable feeling of wellbeing with which most people are familiar.

As it appeals mainly to emotions, humor is unlikely to provoke the same reaction for everyone, hence probably the difficulty to find a satisfying definition. Moreover, just as the complexity of defining children's literature lies in its ever-changing nature, humor also differs "from context to context, from one moment to another", according to Mallan [1993: 7], who adds that "it changes as society changes and it changes as individuals get older". Therefore, as an adult's sense of humor is likely to be different from what a child may find funny or amusing, it may be more relevant, for this article, to look at a possible definition through a children's perspective.

\subsubsection{The children's sense of humor}

As Mallan [1993: 7] rightfully notes:

Humor is not to be confused with laughter, for you can be amused without laughing. The reverse is also true. Some children can't help laughing when they're in trouble, it helps release the tensions they feel.

So, unfortunately, one cannot always rely on a noticeable spontaneous body response such as laughter to confirm that children (as well as adults) find a text or an image funny. Other indicators have to be found and research has been able to determine a number of elements that are likely to provoke amusement in children. For McGhee [2014: 13], "incongruity", that is to say something unexpected or strange happening, plays an important role in children's sense of humor. He however contrasts his statement, reminding that incongruity is far from being a "necessary nor sufficient condition of humor". It is nevertheless a valuable element in this analysis as occasionalisms are unusual words that the reader is probably seeing for the first time. They are perhaps even more likely than regular words to cause a feeling of incongruity and therefore to create a humorous effect. Building on the studies of Kappas [1967] and Klause [1987], Mallan [1993: 9] lists some of the other elements that have been found to trigger a humorous response, in addition to incongruity, such as "[e]xaggeration, surprise, slapstick, absurd, verbal humor, human predicaments, ridicule, defiance and violence". He goes on explaining that linguistic play is indeed a key humorous element in primary as well as older children who "usually enjoy nonsense language and oddsounding or inventive words" (Mallan [1993: 15]). This enjoyment can be explained by the fact that children are still exploring the limits of their own language and that younger children often have the tendency to create, more or less intentionally, words of their own, or to play with sonorities as they talk. Building on Chukovsky's [1963] work, Epstein [2012:34] further refers to the fact that children are themselves very creative with language and that "they show a real enjoyment of sounds". For their incongruity, verbal humor and their tendency to explore the limits of language, occasionalisms are thus extremely likely to arouse children's sense of humor, which partly explains why they are omnipresent in children's literature. The humorous 
function of such nonce formations is clear, though not the only purpose for authors to create them. In the case of Dahl, who was particularly prolific in terms of lexical creations, however, the humorous aim of his made-up words seems to leave little space to doubt.

\section{Gobblefunking with words in Roald Dahl's novel The BFG}

Roald Dahl is no exception in the long-lasting tradition of authors of children's literature playing with words and with language in their writings. With hundreds of invented words, he has created a whole new vocabulary called Gobblefunk which is a mine of precious information on the way occasionalisms in children's literature are formed, and on the effects they are likely to produce on young readers.

\subsection{About choosing The BFG}

With more than 17 novels and poems written for children, in addition to his numerous short stories for a more adult audience, Dahl undeniably remains an important figure of children's literature. From his first children's book in 1943 called The Gremlins to his most successful stories such as Charlie and the Chocolate Factory (1964), Fantastic Mister Fox (1968), The Witches (1983) or Matilda (1988), all of which have been adapted into movies, Dahl has managed to engage numerous children in his fantasy worlds full of magical creatures such as giants, witches and talking animals where adults are definitely not the most welcomed. His writings seem to reflect his facility and enjoyment when it comes to playing with language for what seems to be the fun of it, whether in the form of wordplay, irony, rhymes or parody (see Revolting Rhymes in 1982), as shown by the creation of his famous, and numerous, nonce words.

\subsubsection{Roald Dahl and his Gobblefunk}

With occasionalisms such as buzzburgers, strawbunkles, snozzcumbers, cannybully and other trogglehumper, Dahl seems to delight in always pushing the boundaries of the English language a bit further. In 2016, the Oxford Roald Dahl Dictionary (Dahl \& Rennie [2016]) even compiled all his linguistic inventions and particular usage of words, and gathered more than 500 occasionalisms and character names. Most of the words in Dahl's made-up vocabulary come from his 1982 novel The BFG which tells the story of the unexpected friendship between Sophie, a young orphan, and the Big Friendly Giant who, unlike his fellow giants, strongly opposes to eating humans and prefers collecting dreams to blow in their ears when they are asleep. It is the unusual way in which the BFG expresses himself that constitutes the collection of nonce formations, now called Gobblefunk from one of the giant's famous expressions: "don't gobblefunk around with words!" According to a study led by Poix [2019: 44-45], The BFG contains "18,667 lexical items, among which 3,776 are different words" for a total of " 414 occasionalisms, i.e. $11 \%$ of all lexical items". It is however important to mention that this figure does not reflect the exact amount of nonce formations in the novel as she regrets the technical impossibility for the study to include "semantic neology", that is to say the occasionalisms composed of "real" words such as human beans (the giant's way of 
naming human beings). It is then its incredibly rich content in terms of lexical creations that makes The BFG particularly interesting when it comes to analyzing occasionalisms in the context of children's literature. However, my choosing of this particular novel also comes from the clear intention of the author to use nonce formations to create a humorous effect.

\subsubsection{The author's intention behind his Gobblefunk}

21 This analysis indeed aims at focusing on the humorous effect that can be produced by occasionalisms in children's literature. Although it has been made clear in the first part of this article that humor is not the only function of nonce words, but one among several, nor is it necessarily present is their creation process, in the case of Dahl's Gobblefunk, the humorous intention of the author cannot be neglected. In a 1982 interview for the TV show Pebble Mill at One, broadcast on $B B C 1$, when asked about the difference between writing for children and for adults, Dahl explained:

To my mind, to write a children's book of comparable quality to a fine adult novel or story is more difficult. [...] When you're old enough and experienced enough to be a competent writer, [...] by then you've become pompous and adult, grown-up, and you've lost all your jokiness. Unless you are a kind of undeveloped adult and you still have an enormous amount of childishness in you, and you giggle at funny stories and jokes, I don't think you can do it.

This statement clearly shows the link in Dahl's mind between childhood and fun, amusement and the ability to make jokes. It therefore seems to imply that, as he himself has managed to write so many successful children's books, he must then still possess this ability to laugh at stories that children might find funny, he must still have this "childish sense of humor". Moreover, in another interview, for the TV show Middle English, broadcast on Thames TV in 1989, he states that in order to make a good children's book, "after a great plot, the other vital ingredient is humor, laughs. You simply got to have them [...] and lots and lots of excitement". He continues giving another key element to understand his intention behind the creation of Gobblefunk in the writing process of The BFG:

I got the BFG and I got the little girl but it wasn't very exciting, there was something missing in it. And I kept looking at it and thinking "well yes, it's alright but..." and suddenly I got the idea of him talking funny. And that did it. That excited me quite a lot. And then I had masses of fun with that all the way through!

In light of the author's own declarations on the subject, it makes no doubt that Dahl's intention when inventing new words in his famous novel was primarily to have fun, to create excitement and provoke laughter. As he considered himself to still have that "childishness", necessary according to him to write good children's books, it is therefore likely that he thought that what amused him would also amuse the children reading his work. Humor can in fact be considered central to the writings of Roald Dahl, and it seems that for him incorporating nonce formations to these stories was a way to produce a humorous effect. His Gobblefunk, especially in the case of The BFG, thus probably aimed much more at having a recreational purpose, than at achieving any of the other functions of occasionalisms. 


\subsection{Analysis of the humorous effect of The $B F G$ 's occasionalisms}

Giant. Even though these words seem to come naturally and consistently to him, he sounds well aware of his unusual way of expressing himself and even feels apologetic about it:

(1) What I mean and what I say is two different things, the BFG announced rather grandly.

(2) Words, he said, is oh such a twitch-tickling problem to me all my life. So you must simply try to be patient and stop squibbling. As I am telling you before, I know exactly what words I am wanting to say, but somehow or other they is always getting squiff-squiddled around.

(3) I is speaking the most terrible wigglish.

all the time, most of the BFG's language seems perfectly understandable by his interlocutors, and by extension by the reader. And on the few occasions where it may not be the case, Sophie, by asking him what he means or by guessing the real meaning of his words, serves as a way for the author to make the giant clearer to his audience. The fact that the nonce words created by Dahl are rather easily decipherable is a significant point when analyzing how they have been formed. It indeed reflects the "familiar effect" that occasionalisms very often produce. According to Stockwell [2014: 124], the reason why nonce formations give this impression is because "readers often try to interpret them in terms of words they already know". He moreover questions whether "genuinely new creations of new words" are possible as they generally tend to be formed using pre-existing words or grammatical forms. This participates in confirming what Lecercle [2012: 40] notes when talking about coined words in nonsense literature:

This speciality of nonsense, therefore, is not merely word creation, but regular word creation. [...] As usual, the linguistic imagination of nonsense is highly constrained. It does not invent in a vacuum, but by imitating and exploiting rules.

It therefore appears that the creation of occasionalisms has to follow a certain set of linguistic rules in order to be understandable enough not to obstruct their intended function.

\subsubsection{Categorizing occasionalisms}

Nonce formations can indeed be classified linguistically regarding their types and the specific grammar rules they follow or modify. However, as Poix [2018: §107] interestingly remarks in the conclusion of her extremely complete analysis of the formation of nonce words, "there is no limit to lexical creation and deviation in children's literature". It is therefore not particularly easy to categorize occasionalisms as classification methods can be added as new nonce words are formed. Munat [2007:167] organizes the formation of occasionalisms into two main types: the "morphologically motivated" nonce words and the "phonologically motivated" ones. The latter category seems to be of greater importance in the case of Dahl's work as she considers that the majority of the nonce formations in The BFG indeed relies on phonological play [2007: 175-176]. Perhaps a limit to this classification technique could be that even though some occasionalisms are "phonologically motivated", they have 
nonetheless been created through a morphological alteration, which can greatly complexify their categorization. Epstein [2012:32] identifies four methods of creating new words in the context of "expressive language" in children's literature:

- "novel usage/shifting", which implies using language in a different way (changing its spelling, its grammar category, or its meaning);

- "borrowing", meaning taking a lexical item from another language;

• "creation", or genuinely inventing a word from scratch;

. "modification", which means altering an already existing word.

That interesting model may however lack precision as there can be a multitude of different ways of modifying already existing words. Poix’s classification [2018: \$28] offers this welcomed precision with a much more detailed method. She bases her categories on Tournier's [2007] internal matrices, subdivided into three types of neologisms: morphosemantic, semantic and morphological. This is the classification I have chosen to follow. However, her analysis being extremely complete and already containing many examples from The BFG, I will mainly focus on the way each category conveys the humorous intention of the author rather than going into more unnecessary details regarding the way these occasionalisms are coined.

\subsubsection{Forming humor through nonce words}

Each three of these categories have their own way of producing a humorous effect on the child reader.

\subsubsection{Humor in morphosemantic occasionalisms}

Morphosemantic occasionalisms can be divided in two types according to Poix [2018: \$61]:

The first one is about construction: affixation (prefixation, suffixation and backformation) and composition (compounds and blends). The other concerns phonological motivation with onomatopoeia and ideophones (also called phonaesthesia).

In The BFG, a large number of nonce words are indeed formed by adding an unnecessary or an out-of-place prefix or suffix to a term:
(4) frightsome (instead of frightening)
(5) disgusterous (instead of disgusting)
(6) darksome (instead of dark)
(7) I mispise it (instead of despise)
(8) glamourly (instead of glamorous)
(9) um-possible (instead of impossible)

These occasionalisms are likely to convey the feeling of "familiarity" which makes them rather easily understandable, while giving an odd sentiment to the readers who have, according to Munat [2007:176], "the impression that many of these formations are only slightly 'off". The affixes -some, -ly, -ous, and mis- are indeed all recognizable and perfectly accepted in the English language where they are commonly used to form adjectives or adverbs. They have however been intentionally misplaced here by Dahl who uses this technique as a way to create a humorous effect. The fact that they look familiar and almost linguistically correct, or that they could easily be, is effectively very likely to emphasize the feeling of "incongruity" put forward by McGhee [1989: 13] 
as an important part of children's sense of humor. Similarly, compounds or blends are also a way of triggering humor using incongruity, as they are formed from one or several pre-existing words, which the readers may be able to recognize or guess without too much difficulty. As Munat [2007: 176] explains, contrarily to blends which are a combination of two existing words, compounds are "formed of one recognizable free root combined with a nonsense word or two semantically unrelated words". Here again, these techniques are constantly used in The BFG:
(10) kidsnatched (kid + to snatch)
(11) strawbunkles (strawberry + bunkles)
(12) gobblefunk (to gobble + funk)
(13) natterboxes (to natter + boxes)
(14) horsefeathers (horse + feathers)

Regular English words are indeed easily recognizable in such examples, as "kid", "to snatch", "strawberry", "to gobble", "funk" or "boxes". However, to fully understand the meaning, the reader has to rely on the context and cannot always guess the meaning of these new nonce words on their own, which reinforces the feeling of incongruity likely to provoke humor. Regarding the second type of morphosemantic occasionalisms, the ones phonologically motivated, examples can be found in The BFG in the forms of onomatopoeias (15), alliterations (16) and (17) or ideophones (18) and (19), a term defined as a "representation of an idea in sound" (Doke quoted by Poix [2018: §65]).

(15) Eeeeeowtch! (...) Ughbwelch! Ieeeech!

(16) You is a squinky little squiddler!

(17) The rotten old rotrasper!

(18) Now, this is wizzpopping

(19) A tiny little buzzing-humming noise

As shown in the examples above, such nonce formations are used in Dahl's novel to express an emotion, such as disgust (15), to create insults (16) (17), or to name something after the sound it may make (18) (19). As previously mentioned, sonority and phonology play a great role in children's sense of humor. These occasionalisms playing with sounds may indeed, according to Munat [2007: 178], have an "instinctive appeal to children" who will generally find them funny. Moreover, when considering insults, the formation of such invented words can be reinforced by the fact that children are likely to be entertained by some degree of violence in literature, in this case verbal violence, as described by Mallan [1993: 9].

\subsubsection{Humor in semantic occasionalisms}

The second category, still following Poix’s classification [2018: \$74], contains semantic occasionalisms and can also be subdivided in two types:

The first one is a transposition of grammatical class (conversion). The other one concerns metasemantic processes: metaphor, metonymy (including synecdoche),

figurative meaning and euphemism.

Some examples of the nonce words in this category can of course be found in the mouth of the BFG, who delights in apparently unintentional puns (23), strange metaphors and similes (21) and (22) as well as very unusual collocations (20) and (24): 
(20) Oh save our solos! [...] Deliver us from weasels!

(21) I always gets as jumpsy as a joghopper

(22) You is deaf as a dumpling

(23) The human bean is not a vegetable

(24) Once in a blue baboon

They are likely to produce a humorous effect as they enter the category of verbal humor in general. These examples fall into the category of verbal humor and even combine types of wordplay and occasionalisms which tremendously appeal to children, according to Mallan [1993: 15].

\subsubsection{Humor in morphological occasionalisms}

Finally, the third category includes all morphological occasionalisms, that is to say all nonce formations that alter in one way or another the signifier (Poix [2018: \$85]). They may modify it in terms of orthography (spelling for example) (25) and (26), phonology (27) and (28), lexicality (29), or grammar, and they might also change the length of the word (30), its order in a sentence or the way it is segmented (31):
(25) Teecher
(26) Spheshal
(27) Langwitch
(28) Exunckly
(29) Catasterous disastrophe
(30) Rhinostossterisses
(31) You is a norphan?

Such examples show another way of producing an entertaining effect using verbal humor, which, according to Mallan [1993: 9] quoting Kappas [1967] and Klaus [1987], children seem to enjoy. These creations might also give an impression of exaggeration, if a word is made ridiculously long for instance (30), or convey a sense of absurdity, such as with spoonerisms. As exposed by Mallan [1993: 9], both exaggerated and absurd situations are a way of triggering children's sense of humor, which explains the prolific use of this kind of occasionalisms in The BFG. This category also includes nonce words using "reduplication", which means repeating once or more a word or a part of a word in order to create rhythm (Poix [2018: §97]):

(32) crackety-crack

(33) telly-telly bunkum box

(34) clumpety-clumpety-clump

This technique tends to play on sounds as well, and is therefore likely to amuse and entertain young readers, as previously mentioned. The humorous effect intended by Dahl can indeed be explained when examining how he created the numerous occasionalisms in The BFG. It is now interesting to wonder whether the invention of new words in a literary context is easily translatable in another language, and particularly whether the humorous effect conveyed by these specifically coined lexical items can actually travel across borders. 


\section{Playing with language... in another language}

41 Children's literature, lexical creations and humor are all concepts that are challenging to define, their nature evolving constantly and their limits seeming practically endless. It then comes to no surprise that these three concepts therefore all present their own particular difficulties when it comes to translating them into another language. Translating the numerous humorous occasionalisms in Dahl's The BFG must have undoubtedly been a challenge for its translators around the world. This part will focus on analyzing the French translation of the novel by Jean-François Ménard and the techniques he used to render the humorous effect intended by Dahl.

\subsection{The challenges of translating humorous occasionalisms in children's literature}

42 It indeed appears that the difficulties add up when the question of translating The BFG is raised as it embodies the challenges of translating children's literature, translating lexical creations as well as translating humor.

\subsubsection{Translating children's literature}

43 As the translation of children's literature has been given more and more academic attention over the last three decades, the works of many scholars have shed light on the diverse challenges of this discipline. According to O'Connel [2006: 20-21], similarly to children's literature, translating for children has suffered and continues to suffer from low recognition, both in terms of prestige and financial reward. As Lathey [2006: 1] points out, if the translator is generally already considered as "invisible", the translator of children's literature "seems to be the most transparent of all". This perception however feels particularly unfair regarding the fact that translating children's literature can be "considered as a literary challenge in its own right" according to Coillie \& Verschueren [2014: v]. For a lot of the same reasons that make defining the genre a complex task, translating children's literature implies facing numerous challenges. Similarly to authors of children's literature, translators of the genre are likely to rely on their own conceptions of childhood and on what the society around them thinks is acceptable or not for children to read. As Oittinen [2000:3] notes:

Translators never translate words in isolation, but whole situations. They bring to the translation their cultural heritage, their reading experience, and, in the case of children's books, their image of childhood and their own child image.

The image of childhood may indeed depend on the culture, as well as on the period when the book was written, which complexifies the task of the translator who then might have to adapt the text in order to make it "appropriate and useful for the child [...] and in accordance with the society's notion of what is 'good' for the child" (Shavit [2009:112-113]). In addition to the importance of the image of childhood when translating children's literature, O'Sullivan [2013: 453-454] mentions other specificities of the field that may offer some challenges to the translator of such texts. One of them concerns the degree of foreignness that translators choose to keep in the text. It might on one hand participate in confusing the child, who may not have the cultural references needed to understand a sentence, a word or a situation. On the other hand, 
however, the solution of deleting or changing the text too much could prevent children from discovering new elements outside the society they belong to. These two translation strategies, respectively known as "foreignization" and "domestication" (Venuti [1995: 20]), are central to an important debate when it comes to translating children's literature. As O'Sullivan [2013: 453] remarks:

Translating children's literature is therefore a balancing act between adapting foreign elements to the child reader's level of comprehension, and to what is deemed appropriate, and preserving the differences that constitute a translated foreign text's potential for enrichment of the target culture.

Another specificity of translating children's literature, still according to O'Sullivan [2013: 453-454], regards the multiple addressees a children's book can have: "adults who read as mediators or who read for their own enjoyment, children of different ages, etc.". It may indeed be a factor that translators for children have to take into account in their work, similarly to the probability of children's literature being read out loud. The readability of the translated text should therefore be one of the priorities of both the author and the translator, according to O'Sullivan [2013: 454]. She goes on pointing out the difficulty consisting in children's literature often relying on the use of visuals, that translators have to take into account in some cases, and on the particular use of sounds in the genre. It then "demands imaginative solutions" according to Lathey [2015: 8] and therefore requires from the translator a perhaps even larger dose of creativity. Finally, and more importantly in the context of this analysis, the importance of wordplay, nonce formations and creative language in general increases the complex task that awaits the translator of children's literature. Coillie \& Verschueren [2006: v-vi] thus emphasize that

Often the creative, playful use of language offers an additional challenge in that it requires a special empathy with the imaginative world of the child.

It is interesting to note that this quote echoes Dahl's opinion on the need for authors to retain a sense of childishness if they want to write children's books. It appears that it is essential for translators as well to possess this faculty in order to translate them in a faithful way.

\subsubsection{Translating lexical creations}

47 Occasionalisms, especially in the context of children's literature, indeed represent a particular challenge for translators. Translating them into French, as will be analyzed in this article, tends to add another difficulty since this language seems more reluctant to accept newly coined words than others, according to Weber [2016: 284]. She insists on the fact that creating neologisms is not of particular interest for French-speaking people, quoting Corbeil [1971: 136]:

L'inconscient linguistique des francophones est actuellement hostile aux néologismes. Nous sommes conservateurs, nous n'avons pas le réflexe de créer des mots nouveaux, cela ne nous amuse pas, et quand nous le faisons, c'est avec crainte et tremblement, avec le sentiment d'être sacrilège.

And for French translators still willing to take the risk, other particular challenges await them when it comes to translating occasionalisms. Of course, as Epstein [2012: 23] rightfully notes, lexical creations are obviously not in dictionaries and the first difficult part of the translation process would be to decrypt their meaning without any lexicological support. Brisset et al. [2019:10] consider that the first step when 
translating nonce formations is to recognize and to be able to understand how they have been constructed by the author. Analyzing such linguistic processes requires an additional ability on the part of the translator who then needs to find an equivalent for the invented terms. For Weber [2016: 291], what is more important than translating mere words is to render the writing style of an author. It is even more necessary for translators to identify the reason behind the original creation of the occasionalism under study, its function. Being able to identify the functions of the nonce formations and finding a way to render them in another language is thus essential. Regarding their humorous function, translators need again to be prepared to face another kind of challenge.

\subsubsection{Translating humor}

The translation of humor is in fact a delicate matter, which only adds up to the difficulties of translating children's literature and occasionalisms. The main reasons for this complexity and the reason why humor is often considered "untranslatable" are that it generally heavily relies on cultural and linguistic particularities which do not travel well across borders. According to Moura [2019: 24], humor is strongly linked to the community it comes from and it is therefore challenging for the translator to render its effect in another language, as it is aimed at another cultural context. As Chiaro [2010:21-22] puts forward, the translation of humor is "above all an intercultural [problem]" since it greatly relies on the audience's own cultural codes and references. Moreover, when humor relies on wordplay or linguistic jokes as it often does, it is important to note that language equivalences are very often hard to find, sometimes even impossible to achieve (Chiaro [2010: 8]). Such challenges regarding the translation of humor are even more demanding when the humorous effect depends on manipulations of the language itself, as is the case in The BFG. Roald Dahl intentionally pushes the boundaries of the linguistic conventions of the English language in order to amuse his readers. The difficulties are then numerous for translators in charge of working on such a humorous children's book and its many occasionalisms.

\subsection{Translating The BFG's humorous occasionalisms}

The BFG, published in 1982 in its original language, was translated in French two years later by Jean-François Ménard, who sometimes also writes and translates under the pseudonym Camille Fabien. His work in adapting Dahl's lexical creations to the Frenchspeaking audience will be examined in this section in order to analyze the translation process and strategies implemented to render the occasionalisms in The BFG into French. The way the author's intended humorous effects have been translated will be particularly under study as it appears to be the main purpose in creating such numerous nonce formations in the original novel.

\subsubsection{The translation process}

51 In order to help translators in their task when working on occasionalisms in children's literature, Epstein [2012: 38] suggests a six-step process: the first one is to recognize the function of the nonce word, the second to examine how it was coined by the author, then to analyze its meaning and sonority, the fifth step is to take the culture and the 
children's perspective into account, and finally the final step consists in relying on previous translations (if available) before identifying a final translation strategy. Recognizing the function is indeed the first essential step as it is the fact that the translation will be able to render the same effect as the original text which matters most. Relying on Vermeer's skopos theory [1989], Chiaro [2010: 9] states that "as long as the target text serves the same function as the source text [...], it is of little importance if the target text has to depart somewhat in formal terms from the original". Translating the general humorous effect when translating The BFG should therefore be considered a priority. Even though according to Weber [2016: 291], occasionalisms in children's literature are usually "more or less transparent", some additional help might be needed in some cases to clearly identify their meaning. Poix [2019: 42] suggests for example relying on the context, which is very likely to give significant clues to the reader and the translator alike. She further indicates that it is not rare for the author to use another character to clarify the sense of a nonce word, whether by asking for some explanation of the term or for a translation. It is often the case in The BFG through the character of Sophie, who regularly plays this particular role:

(35) You mean jerseys, Sophie said.

(36) What do you mean? Sophie said.

(37) He means helicopters, Sophie told him.

Illustrations can also be helpful to grasp the meaning of a newly coined word or to understand a situation. The ones drawn by Quentin Blake in The BFG indeed offer precious information. By the look on the face of the BFG when he eats a snozzcumber, both the reader and the translator can get a clear idea of the intention behind the words that describe the invented vegetable and they can easily guess that disgusterous, sickable, rotsome, maggotwise or foulsome are definitely not used to indicate that the giant is enjoying his meal.

\subsubsection{Strategies of translation}

53 After identifying the function and meaning, with the help of the context or the co-text, the translator, Jean-François Ménard in the case of Le BGG: le Bon Gros Géant, had to choose a translation strategy to render occasionalisms in French. Epstein [2012: 39] states that these strategies are up to five: retention, adaptation, replacement, explanation and deletion. Ménard's translation choices in The BFG do not seem to favor the retention or explanation strategies. The first one means keeping the occasionalism as it is coined in the original text, which according to Epstein [2012: 40] works best "in the case of languages that are related and/or have similar-sounding words", which is not particularly the case with English and French. Ménard does sometimes use the explanation strategy, which consists in adding in the text or in the paratext some information about the nonce word in order to make it clearer (Epstein [2012: 40]), but he only does it when Dahl has used this technique in the original. It therefore cannot be considered entirely as a translation strategy as such for nonce words. Adaptation, which Epstein [2012:40] describes as changing the spelling or grammar of an occasionalism, is not a particularly popular strategy either for Ménard, who uses it only on rare occasions, generally in the case of some of the giants' names, then translated literally: 
(38) Childchewer > Mâcheur d'enfants

(39) Bonecruncher > Croqueur d'os

Deletion, or the fact of completely removing an occasionalism from the text is sometimes used by Ménard, but the main strategy he chooses is replacement, which consists in also creating a nonce word in French.

\subsubsection{Translating Dahl's humor in French}

To analyze how these replacements have been made and to determine whether they successfully serve the humorous purpose of the author, I have chosen to use Poix's [2019] method of classification once again, focusing once more on humor.

\subsubsection{Translating humor in morphosemantic occasionalisms}

In the case of affixation, as the same technique is easily applicable in French, the translator has been able to adapt this method quite easily by adding unusual affixes, which nonetheless exist in French, to different words:

(40) disgusterous > répugnable / dégoûtable

(41) I mispise it > je le vilprise

However, we can note that Ménard probably did not find as many possible and inventive combinations as Dahl, since he chose the same translation for different words, such as repulsant and disgusterous which he both translated as répugnable (changing the normal suffix -ant of the word répugnant to the suffix -able). He also chose to replace some of these occasionalisms by existing words or expressions, instead of other nonce formations in French. It is notably the case of sickable, that he translated by à tomber malade, or glamourly which he chose to translate by délectable. Other occasionalisms are lost, such as frightsome, translated alternatively by the lexicalized French terms effroyable and épouvantable, or darksome night simply translated by nuit noire. But to compensate, and as Ménard seems to enjoy using this way of coining occasionalisms, some are created even if the source text offers another process of word creation:

(42) glummy > savourable

(43) scrotty > mélancoleux

He also manages to find creative solutions by replacing some occasionalisms by another play on words. For instance, he sometimes creates morphological occasionalisms instead, as in the following example:

(44) um-possible > un pot cible

Compounding and blending are also techniques which most of the time seem to travel easily from English to French:

(45) kidsnatched > kidnattrapée

(46) strawbunkles > framboiserie

(47) gobblefunk > blablatifoler 
nd if others are actually created like succuxcellent, which blends succulent and excellent (for glumptious), many are nonetheless lost in Ménard's translation, replaced by regular, though original, words and expressions:

(48) clockcoaches > ver de vase

(49) You little swinebuggler! > Espèce de goret bâtard !

(50) You little pigswiller! > Sale mâchouilleur d'épluchures !

The morphosemantic occasionalisms playing on phonology, such as onomatopoeias are generally adapted into sounds which would be more familiar to a French ear and, interestingly enough, they tend to have more repeated letters and be followed by more exclamation marks than in English. It might be a way of exaggerating even more, which is, as we have seen, likely to create a funny effect among children:

(51) Eeeeeowtch! [...] Ughbwelch! Ieeeech! > Aaaaaaeuuuuuuâââââârk !!! [...] Aaaapouuuuuhhhh! Spouuuuuââââââshhh

(52) Eeeow! [...] Ayeee! Oooow! > Ouaaaah, [...] Aiïiïiîî̀aaayouuillllle !!!

The creative ideophone whizzpopping is replaced by crépitage which does render the idea of a particular sound, though perhaps not as originally as Dahl's occasionalism. However, other ideophones are lost, such as buzzing-humming noise which is soberly translated by the real word bourdonnements. In terms of humor, although perhaps less frequent since many have been replaced by regular words and expressions, the translation of morphosemantic occasionalisms by Ménard is likely to produce the same effect of incongruity which tends to trigger children's sense of humor. The French translation however tends to miss out on the occasion of playing with sounds and sonorities as much as Dahl does, and which seems to appeal so much to children.

\subsubsection{Translating humor in semantic occasionalisms}

63 The category of semantic occasionalisms, which gathers nonce words using wordplay such as puns, metaphors and similes or collocations is not so successful, as they are often lost in Ménard's translation. Collocations seem to be the most likely to be translated by another unusual set of words:

(53) Oh save our solos! [...] Deliver us from weasels! > Misère discorde!

Délivrez-nous du râle!

(54) into thick ear > coude en l'air

(55) skin and groans $>$ la peau et les mots

64 Some exceptions have to be noted however, such as the disappearing of once in a blue baboon, which is soberly translated as une fois et quelque. Similes are reproduced but often unfortunately lose the occasionalisms they contain:

(56) as jumpsy as a joghopper > plus nerveux qu'une étincelle

Verbal humor then seems to travel across borders a bit less effectively and may be harder to translate in some cases. However, Ménard's creative translation of the majority of Dahl's collocations is likely to produce the same humorous effect, as he follows the same creation process as the author. 


\subsubsection{Translating humor in morphological occasionalisms} genre of children's literature makes it particularly challenging to study, Dahl's novel The BFG, which contains the vast majority of his made-up vocabulary called Gobblefunk, is an interesting object of research when it comes to analyzing the translation of the humorous effects of occasionalisms in children's books. The clear intention of the author of entertaining the readers through the creation of nonce words and the use of a particularly playful language in fact encourages the examination of the way these occasionalisms have been translated into other languages, as humor is known not to travel across borders easily. It indeed appears that, in accordance with the skopos theory, it is in fact the function of a text that primarily needs to be translated and not mere words, even the invented ones. Ménard's French translation of The BFG offers an interesting way of considering the question. Using mostly the same processes to create 
nonce words in French than Dahl in English, he effectively manages to render the characteristics likely to trigger children's sense of humor. Verbal humor conveying a sensation of incongruity, of absurdity, of exaggeration, and even sometimes of verbal violence which are all likely to entertain young readers are indeed present in his work. It is important to note however that the French translation has a smaller number of occasionalisms overall, as Ménard has sometimes chosen to translate nonce formations by already existing words or expressions. He does intend to keep as much wordplay as possible, but perhaps, after all, Corbeil [1971:136] was right in saying that the French language is more reluctant to create occasionalisms than some other languages. It may indeed be one of the reasons why many of Dahl's lexical creations have been replaced by existing words in French, and also why Ménard has decided not to translate the constant grammatical mistakes of the BFG (I is reading, or giants is making) which do not transpire at all in the French text. The humorous effect produced by Dahl's nonce formations have on the whole been effectively rendered by Ménard, though probably to a lesser degree, which may be explained by cultural preferences and national acceptance in terms of linguistic manipulations. It would be interesting to compare the findings of the present study to the less known French theatrical translation (and adaptation) of The BFG by Jean Esch, as well as to translations of the novel into other languages. Analyzing in more detail the cultural and linguistic reasons of the apparent resistance of the French language to the creation of occasionalisms and comparing them to the evident inclination of the English language to do the exact opposite would also be a promising study.

\section{BIBLIOGRAPHY}

\section{Corpus}

DAHL Roald, 2007 (1984), Le BGG : le Bon Gros Géant, Paris: Gallimard.

DAHL Roald, 2013, Le Bon Gros Géant : Le BGG. Pièces pour enfants. Paris: Folio Junior.

DAHL Roald, 2016 (1982), The BFG, London: Penguin Random House.

DAHL Roald \& RENNIE Susan, 2018 (2016), Oxford Roald Dahl Dictionary: From Aardvark to Zozimus, a Real Dictionary of Everyday and Extra-Usual Words, Oxford: Oxford University Press.

\section{References}

BATOR Robert, 1983, Signposts to Criticism of Children's Literature, University of Michigan: American Library Association.

BRISSET Frédérique et al. (Eds.), 2019, Du Jeu dans la Langue : Traduire le Jeu de Mots, Villeneuve-

d'Ascq: Presses Universitaires du Septentrion.

CHIARO Delia (Ed.), 2010, Translation, Humour and Literature: Translation and Humour Vol. 1, London/ New York: Continuum Bloomsbury.

CHUKovsky Korney, 1963, From Two to Five, Berkeley: University of California Press. 
COILLIE Jan van \& VERSCHUEREN Walter P. (Eds.), 2014 (2006), Children's Literature in Translation: Challenges and Strategies, Abingdon: Routledge.

CORBEIL Jean-Claude, 1971, « Aspects du problème néologique », La banque des mots : revue semestrielle de terminologie française 1/2, 123-136.

EPSTEIN B.J., 2012, Translating Expressive Language in Children's Literature: Problems and Solutions, Oxford: Peter Lang.

HOHENHAUS Peter, 2007, "How to Do (Even More) Things with Nonce Words (Other Than Naming)", in MUNAT Judith (Ed.), Lexical Creativity, Texts and Contexts, Amsterdam/Philadelphia: John Benjamins, 15-38.

HUNT Paul (Ed.), 2000 (1999), Understanding Children's Literature, London and New York: Routledge. KAPPAS Katherine H., 1967, “A Development Analysis of Children's Responses to Humor”, Library Quarterly, Vol. 37, 67-77.

KLAUSE Annette Curtis, 1987, “So What's So Funny, Anyway?”, School Library Journal, February 1987, 34-35.

LATHEY Gillian, 2006, "The Translator Revealed: Didacticism, Cultural Mediation and Visions of the Child Reader in Translators' Prefaces”, in COILLIE Jan van \& VERSCHUEREN Walter P. (Eds), 2014 (2006), Children's Literature in Translation: Challenges and Strategies, Abingdon: Routledge, 1-18. LATHEY Gillian (Ed.), 2006, The Translation of Children's Literature: A Reader, Clevedon: Multilingual Matters.

LATHEY Gillian, 2015, Translating Children's Literature, Abingdon: Routledge.

LECERCLE Jean-Jacques, 2012 (1994), Philosophy of Nonsense. The Intuitions of Victorian Nonsense Literature, Abingdon: Routledge.

LIPKA Leonhard, 2002, English Lexicology: Lexical Structure, Word Semantics \& Word-Formation, Tübingen: Gunter Narr Verlag.

MALLAN Kerry, 1993, Laugh Lines: Exploring Humour in Children's Literature. Literature Support Series, Newtown: Primary English Teaching Association.

MATtiello Elisa, 2017, Analogy in Word-Formation: A Study of English Neologisms and Occasionalisms, Berlin: de Gruyter Mouton.

MCDOWELL Myles, 1973, "Fiction for Children and Adults: Some Essential Differences", Children's Literature in Education $4 \mathrm{n}^{\circ} 1$, Basel: Springer, 50-63.

MCGHEE Paul E. (Ed.), 2014 (1989), Humor and Children's Development: A Guide to Practical Applications, Abingdon: Routledge.

MOURA Jean-Marc, 2019, “Jeux de mots, humour et traduction”, in BRISSET Frédérique et al. (Eds.), 2019, Du Jeu dans la Langue : Traduire le Jeu de Mots, Villeneuve-d'Ascq: Presses Universitaires du Septentrion, 19-32.

MUNAT Judith (Ed.), 2007, Lexical Creativity, Texts and Contexts, Amsterdam/Philadelphia: John Benjamins.

MUNAT Judith, 2007, "Lexical Creativity as a Marker of Style in Science Fiction and Children's Literature", in MUNAT Judith (Ed.), Lexical Creativity, Texts and Contexts, Amsterdam/Philadelphia: John Benjamins, 163-185. 
NODELman Perry, 2008, The Hidden Adult: Defining Children's Literature, Baltimore: Johns Hopkins University Press.

O'CONNELL Eithne, 2006, “Translating for Children”, in LATHEY Gillian (Ed.), The Translation of Children's Literature: A Reader, Clevedon: Multilingual Matters, 15-38.

o'sulLIVAN Emer, 2005, Comparative Children's Literature, Abingdon: Routledge.

OITTINEN Riitaa, 2000, Translating for Children, New York and London: Garland Publishing, Inc.

PoIx Cécile, 2018, “Neology in Children's Literature: A Typology of Occasionalisms”, Lexis. Journal in English Lexicology 12.

PoIX Cécile, 2019, «Les jeux de mots dans la littérature pour la jeunesse : typologie des procédés de (ré)création lexicale et stratégies de traduction des création ex nihilo », in BRISSET Frédérique et al. (Eds.), Du Jeu dans la Langue: Traduire le Jeu de Mots, Villeneuve-d'Ascq: Presses Universitaires du Septentrion, 35-51.

ROSE Jacqueline, 1992, The Case of Peter Pan or the Impossibility of Children's Fiction, Philadelphia: University of Pennsylvania Press.

SHAVIT Zohar, 2009 (1986), Poetics of Children's Literature, Athens: University of Georgia Press. STOCKWELl Peter, 2014, The Poetics of Science Fiction, Abingdon: Routledge.

TAXEL Joel, 2002, “Children's Literature at the Turn of the Century: 'Toward a Political Economy of the Publishing Industry", Research in the Teaching of English 37, no. 2, Philadelphia: National Council of Teachers of English, 145-197.

TOURNIER Jean, 2007 (1985), Introduction descriptive à la lexicogénétique de l'anglais contemporain, Genève: Slatkine Érudition.

VENUTI Lawrence, 1995, The Translator's Invisibility: A History of Translation, Abingdon: Routledge. VERMEER Hans Josef, 1989, "Skopos and Commission in Translational Action”, in CHESTERMAN Andrew (Ed.), Readings in Translation Theory, Helsinki: Finn Lectura, 173-187.

WEBER Anne, 2016, “La formation des mots comme problème de traduction”, in ALBRECHT Jörn \& MÉTRICH René (Eds.), Manuel de traductologie, Berlin/Boston: de Gruyter, 275-294.

The Official Roald Dahl Website, https://www.roalddahl.com

Videos

“Roald Dahl's Writing Routine", BBC Archive, 1982: https://www.bbc.co.uk/archive/roald-dahlswriting-routine/zrhdgwx

Nicholson Mavis, 1984, “Roald Dahl Interview, Children's Author, A plus 4", Thames TV, 2019: https://www.youtube.com/watch?v=w3NEMdwkIlo

\section{ABSTRACTS}

Children's literature overflows with examples of lexical creations and linguistic manipulations. Inventing new terms, playing with words and with language in general has indeed become a characteristic of the genre. Although such a tendency has different functions, this paper focuses on the humorous effect that these lexical creations may have on young readers. Using Roald Dahl's made-up vocabulary called Gobblefunk as a case study, this article first analyzes the linguistic mechanisms behind his creative neologisms and attempts to unravel the author's 
intention behind them. It then reflects on the way these lexical creations have been translated into French and comments on their effectiveness to convey the humorous effect of the original text.

La littérature pour la jeunesse fourmille d'exemples de créations lexicales et de manipulations linguistiques. Inventer de nouveaux termes, jouer sur les mots et sur le langage en général est ainsi devenu une caractéristique du genre. Bien que cette tendance ait différentes fonctions, cet article se concentre sur l'effet humoristique que ces créations lexicales sont susceptibles de produire sur de jeunes lecteurs. Utilisant le vocabulaire inventé, appelé Gobblefunk, de Roald Dahl comme étude de cas, cet article analyse tout d'abord les mécanismes linguistiques qui structurent ses occasionalismes créatifs et tente de révéler l'intention de l'auteur à l'œuvre derrière ces constructions. Il étudie ensuite la façon dont ces créations lexicales ont été traduites en français et commente leur efficacité à reproduire l'effet humoristique du texte original.

\section{INDEX}

Mots-clés: littérature jeunesse, occasionalismes, humour, traduction, créativité lexicale, Roald Dahl, Gobblefunk

Keywords: children's literature, occasionalisms, humor, translation, lexical creativity, Roald Dahl, Gobblefunk

\section{AUTHOR}

INÈS ZORGATI

zorgati.ines@gmail.com 